\title{
MEDICINE POISONING IN SUICIDAL PATHOLOGY
}

\section{AUTHORS}

Ljušic D. ${ }^{1}$, Filipović Danić S. ${ }^{2}$

${ }^{1}$ Psychiatry Clinic, Clinical center Priština, Gračanica

${ }^{2}$ Medical Faculty University in Priština-Kosovska Mitrovica
CORRESPONDENT

Ljušić Dragan

KBC Pristina

drljusic@gmail.com

\section{SUMMARY}

Uvod: Investigations shows that on every realized suicide comes 8 to 25 non realized attempts. Individuals which tried suicide with medicine poisoning mostly quote that they have been overwhelmed with feelings and thoughts which was unbearable in that moment. They wished to escape from that unbearable situation or they lost self control. Between individuals whom tried suicide with medicine poisoning, desire to really die, to disappear was very rare. Mostly it was wish "just to sleep a little, to take a rest, make pause". Aim of work: to identified most frequently method for suicidal attempt in both sex and resources which was used in these purposes. Results: most frequently method for suicidal attempt for both sex in our investigation was medicine poisoning - $91,1 \%$, veins cutting - 5,4\% and jump from height - 3,6\%. Mostly used medicines were anxiolytics - $55,4 \%$, combination of different drugs - $25,0 \%$, antidepressants - $8,9 \%$, neuroleptics - $7,1 \%$, drugs and alcohol $3,6 \%$. Most frequent method for suicidal attempt in both sex was medicine poisoning. From drugs most frequently used drugs were anxiolytics and in minimum percent combination of drugs and alcohol. After suicidal attempt $90 \%$ of individuals experienced relief because their suicidal attempt was unsuccessful. In $3 \%$ individuals there was new suicidal attempt on same way, medicine poisoning.

Key words: suicidal attempt, medicine poisoning

\section{SRPSKI}

\section{TROVANJE LEKOVIMA U SUICIDALNOJ PATOLOGIJI}

Ljušic D. ${ }^{1}$, Filipović Danić S. ${ }^{2}$

${ }^{1}$ Klinika za psihijatriju, KBC Priština, Gračanica

${ }^{2}$ Medicinski fakultet Priština, Kosovska Mitrovica

\section{SAŽETAK}

Introduction:Istraživanja pokazuju da svako realizovano samoubistvo prati od 8 do 25 neuspelih pokušaja. Osobe koje su pokušale samoubistvo samotrovanjem najčešće navode da su bile preplavljene osećanjima i mislima koje su im bile nepodnošljive. Želele su da pobegnu iz, za njih u tom trenutku, nepodnošljive situacije, ili su izgubili kontrolu nad sobom. Kod osoba koje su pokušale samoubistvo, trovanje lekovima, želja da zaista umru, da nestanu, javlja se retko. Češće je prisutna potreba da „samo“ odspavaju, odmore se, naprave pauzu. Cilj rada: identifikovati najčešći način pokušaja samoubistva kod oba pola ispitanika i sredstva koja su upotrebljena u cilju izvršenja samoubistva. U našem istraživanju najčešći način pokušaja samoubistva kod oba pola je trovanje lekovima - $91,1 \%$, sečenje vena $-5,4 \%$, skok sa visine - $3,6 \%$ ispitanika. Najčešće korišćeni lekovi su anksiolitici - 55,4\%, kombinacije različitih lekova - 25,0\%, antidepresivi - 8,9\%, neuroleptici - 7,1\%, lekovi i alkohol - 3,6\%. Zaključak: najzastupljeniji način pokušaja samoubistva kod oba pola ispitanika je trovanje lekovima. Od lekova u najvećem procentu korišćeni su anksiolitici a u najmanjem procentu kombinacija alkohola i lekova. Nakon pokušaja samoubistva $90 \%$ ispitanika su osećali olakšanje što im pokušaj samoubistva nije uspeo. Kod $86 \%$ ispitanika na izbor sredstva u cilju samoubistva uticala je laka dostupnost lekova. Kod 3\% ispitanika je bio ponovljeni pokušaj samoubistva i to na isti način, trovanje lekovima.

Ključne reči: pokušaj samoubistva, trovanje lekovima 


\section{INTRODUCTION}

Suicidal behavior some persons is more focused to life and less expression striving to death. In these persons is visible element of invocation for help, drawing attention to itself, indication of danger, that the person is in crisis and need help. Such persons feel helpless to solve their proble$\mathrm{ms}$, have experience that are not accepted by the environment, need care, support, protection and the love of others $(1,2)$.

Data center for poison control point to the millions of cases poisoning due to an overdose of drugs, and acute drug poisoning represent one of the major causes of death. Growing trend of drug poisoning is present both in the world and in our country, where are the most common poisoning with psychoactive drugs, especially benzodiazepines. Benzodiazepines class includes numerous drugs which differ from one another in strength, length of operation, activity of metabolites and clinical use. The dominant effect of benzodiazepines is pharmacologically anxiolytic, possess and hypnotic effect, while depressants effect on the cardiovascular and central nervous system is much less pronounced. However, most symptoms in acute poisoning is result of sedative effect on central nervous system in which these drugs act by stimulating inhibitory effect of transmitter GABA. Especially is toxic a combination of alcohol and benzodiazepines, because it may potentiate the depressive effects of alcohol on central nervous system. The most common signs of poisoning by benzodiazepines are milder disorders of consciousness (somnolence, spoor), ataxia, hyporeflexia and areflexia, mydriasis and nystagmus, behavioral disorders. Yet an increasing number of cases where disorders of seriously character are described: serious disturbances of consciousness (to level of coma), circulatory collapse, cardiac rhythm disorders and respiratory depression. Fatalities can get an overdose of benzodiazepines alone (especially those with short-acting), or in combination with other drugs $(3,4,5)$.

Two major factors in selecting funds are the primary intention and characteristics of suicidal behavior (selfdestruction, appeal alarm function), plus a choice of funds, places and other elements of situational nature. The technique of suicide is somewhat symbolic and symptomatic for suicidal persons, for their gender, profession, social status, their psychological state. Drugs poisoning is more common in women, doctors, pharmacists, younger persons, those in whom in suicidal behavior prevails appeal alarm function...(6).

\section{AIM OF WORK}

Aim of work was to identify most common method of suicide attempts in both sexes and tools that are used for the purpose of suicide.

\section{MATERIALS AND METHODS}

At the psychiatric department of Hospital Center Priština, Gračanica, research was done on sample of 56 patients (42 women and 14 man) wherein the diagnosis suicide attempts (Tentamen suicidii). In this study we use questionnaire, descriptive and analytical statistical methods. From descriptive are used absolute and relative numbers (n, \%), and from analytical chi-square test. Data were analyzed in SPSS (IBM, corp) software program. The results are presented in graphs.

\section{RESULTS}

The most common methods of suicide attempts in both sexes are: poisoning - $91,1 \%$, jump from a height - 3,6\%, and cutting veins $-5,4 \%$. The difference between groups was statistically significant $(X 2=9.569 ; p=0.019)$. Chart No.1



The most commonly used drugs for the purpose of poisoning, suicide attempts were anxiolytics - $55,4 \%$, antidepressants $-8,9 \%$, neuroleptics $-7,1 \%$, combinations of different drugs - $25,0 \%$, drugs and alcohol $-3,6 \%$. The difference between groups was not statistically significant $(X 2=2.935 ; p=0.569)$. Chart No. 2

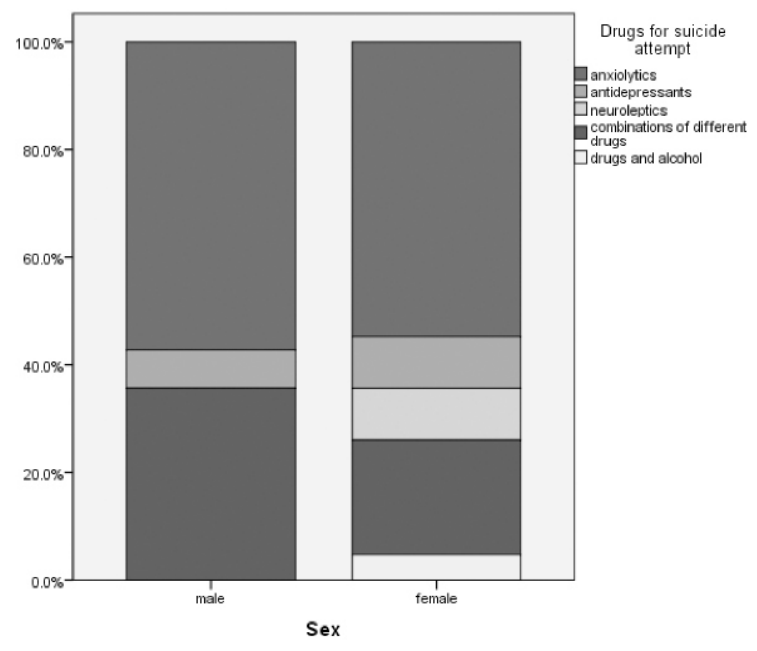

Based on questionnaire, $90 \%$ of respondents after attempting suicide felt relief as they attempt failed; in $86 \%$ of respondents the choice of means which is used for the purpose of suicide is influenced by the easy availability of drugs; $3 \%$ of the respondents was repeated suicide attempts and in the same way, drugs poisoning. 


\section{DISCUSSION}

Investigations shows that on every realized suicide comes 8 to 25 non realized attempts. The most frequent methods of suicide in the world are firearms - $57 \%$, poisoning $39 \%$, hanging $-19 \% .$. (WHO 7 ).

Most frequently method for suicidal attempt for both sex in our investigation was medicine poisoning - 91,1\%. Mostly used medicines were anxiolytics - 55,4\%, then combination of different drugs, antidepressants, neuroleptics, and the lowest percentage was for combination of alcohol and drugs $3,6 \%$. The questionnaire showed that for the majority of respondents dominant feelings and thoughts that preceded the suicide attempt was a desire to escape for them at that moment unbearable situation, that they have lost control of themselves. The desire to actually die, to disappear never existed, but needs "just to sleep a little, to take a rest, make pause". This is an indication that in attempted suicides prevails appeal alarm function. Suicidal behavior can be a way of communication person in crisis with environment. Testing parents, partners and friends to understand who really loves and cares about them, people in crisis want help to overcome the crisis, expecting to show their feelings.

After attempting suicide $90 \%$ of respondents felt relief as they attempt failed.

There are studies that clearly showed that a number of people suffer from intense feelings of fear, emotional tension, emotional pain... $(8,9)$. When such a long-lasting psychological states are present a person can become hypersensitive and the tolerance of suffering become greatly reduced. Gradually coming to overwhelming desire that this suffering, at least temporarily, but certainly interrupted, to have a little rest, to sleep, make pause. Death as solution is not provided here consciously but only as a wish for respite. The patient than takes sleeping pills or tranquilizers or sedative (drugs for pain), or all together to make suffering as quickly and as safely interrupted. It often comes to after the first dose of medication awareness to cloud consciousness and what little control over the situation loses, and then extended with automated or uncontrolled ingestion of drugs to toxic or lethal doses.

In $3 \%$ of the respondents was repeated suicide attempt and in the same way, drugs poisoning.

The period of the greatest risk for re-attempted suicide is three months after first attempt (7).

One study showed that patients who attempted suicide by overdose, and up to $50 \%$ repeat attempt in the next 12 months, between 1 and 11\% finally kill themselves (10).

Person who tried to commit suicide by poisoning it is necessary to provide emergency psychiatric help and effective psychotherapeutic treatment. Aim for a person who has attempted suicide is to accept life and directed toward him, to change his unrealistic perception, attitudes and expectations, to successfully confront problems, and to develop more mature models of perception and behavior.

From the highest percentage of drugs are used anxiolytics $(55,4 \%)$, and the lowest percentage $(3,6 \%)$ combination of alcohol and drugs.

Poisoning with anxiolytics, both individually and in combinations with each other and in combination with alcohol for many years is at the top of frequency of drug poisoning. The reasons lie in the fact that they are readily available funds to be applied in almost all branches of medicine, as well as in the inadequate control of prescribing and dispensing of these drugs.

\section{CONCLUSION}

The most common method of suicide attempts in both sexes was drugs poisoning. From the highest percentage of drugs were used anxiolytics. Most of the respondents felt relieved that their suicide attempt failed, suggesting that drug poisoning suicide in order to prevail appeal-alarm function. The choice of the means that were used for the purpose of suicide is influenced by the easy availability of drugs.

\section{LITERATURE}

1. Hendin H., Maltsberger J.T., Szanto K.: The role of intense affective states in signaling a suicide crisis. J Nerv Ment Dis, 195(5): 363-8; 2010.

2. Vlajković J.: Životne krize, prevencija i prevazilaženje. Beograd, Žarko Abulj; 2005.

3. Godišnjak Centra za kontrolu trovanja. Vojnomedicinska akademija; 2010.

4. Nacionalni registar lekova, 2013. Agencija za lekove i medicinska sredstva Srbije, Grafolik, Beograd; 2013.

5. Coben J.H., Davis S.M., Furbee P.M., et al.: Hospitalizations for Poisoning by Prescription Opioids, Sedatives, and Tranquilizers. Am J Prev Med, 38(5): 517-24; 2012.

6. Bryan C.J., Rudd M.D.: Advances in the Assessment of suicide risk. J Clin Psychol: In Session 62: 185-200; 2010.

7. World Health Organization. Suicide prevention. http://www.who.int/mental-health/ prevention/suicide/suicideprevent/en; 2011.

8. Robinson H., Graham Fuller V.: Understanding Narcissim in Clinical Practice. London Karanc; 2007.

9. Mann J.J., Arango V.A., Avenevoli S., et al.: Candidate endophenotypes for genetic studies of suicidal behavior. Biol Psychiatry, 65: 556-563; 2012.

10. Shafer D., Piancentini R.: Suicide and attempted suicide. In: Rutter M., Teylor E., Hersov L. (editors): Child and adolescent psychiatry: modern approaches. Oxford: Blackwell Scientific Publications; 2011. 